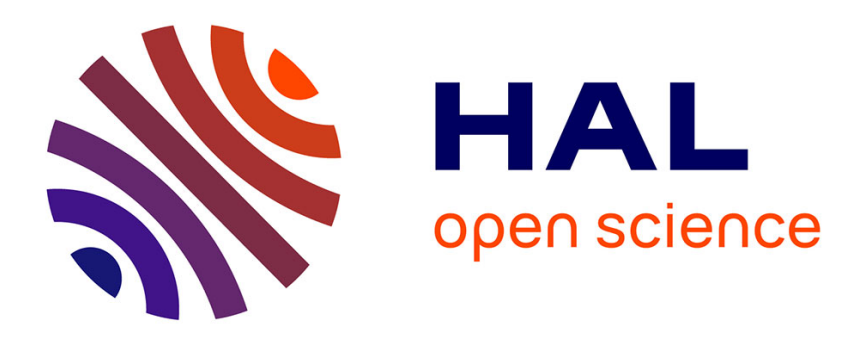

\title{
Co-regulation in Practices: The Hygiene Package in French Slaughterhouses
}

\author{
Laure Bonnaud, Jérôme Coppalle
}

\section{To cite this version:}

Laure Bonnaud, Jérôme Coppalle. Co-regulation in Practices: The Hygiene Package in French Slaughterhouses. Sociologia Ruralis, 2013, 53 (4), pp.479-495. 10.1111/soru.12021 . hal-02645363

\section{HAL Id: hal-02645363 \\ https://hal.inrae.fr/hal-02645363}

Submitted on 29 May 2020

HAL is a multi-disciplinary open access archive for the deposit and dissemination of scientific research documents, whether they are published or not. The documents may come from teaching and research institutions in France or abroad, or from public or private research centers.
L'archive ouverte pluridisciplinaire HAL, est destinée au dépôt et à la diffusion de documents scientifiques de niveau recherche, publiés ou non, émanant des établissements d'enseignement et de recherche français ou étrangers, des laboratoires publics ou privés. 


\title{
Co-regulation in Practices: The Hygiene Package in French Slaughterhouses
}

\author{
Laure Bonnaud* and Jérôme Coppalle
}

\begin{abstract}
In Europe, the food safety policy combines the regulatory interventions of member states with private standards. The Hygiene Package, which came into force on the I January 2006 , is characteristic of this model. The aim of our article is to show that whilst we can learn about co-regulation by examining the standards and principles on which it is based, we will gain an even better understanding by examining its actual implementation. From a sociological standpoint, we look at how the Hygiene Package was received and implemented in French slaughterhouses. (I) After setting out the structure of slaughterhouses in France and the ways in which veterinary services are organised, (2) the article looks at how inspection services have been affected by the introduction of the Hygiene Package, particularly with regard to the changes in relationships within the inspection service, between veterinarians and official auxiliaries and (3) it then examines the evolution in roles and responsibilities between veterinary services and food business operators.
\end{abstract}

'The French authorities have continued their work on implementing the 'hygiene package' in meat and dairy establishments. Official checks are carried out on the basis of a risk analysis and in a co-ordinated and consistent manner. (...) The observations which were made attested to the existence of unhygienic work processes: a whole series of stored bovine and horse carcasses showed visible signs of contamination (hairs, faecal matter); pig carcasses were poorly shaved; barrels of blood (for human consumption) contained dried scabs and dirt mixed in with the blood; in addition, the equipment used to collect pig blood was inappropriate, corroded, dirty. The gutting room was in an even more disastrous state, with manure and animal waste in a great many places, a 'Parmentière machine ${ }^{\mathrm{I}}$ covered with hairs, waste and dirt. Furthermore, category I and 3 animal waste was stored here. The tripe butcher's clothing was disgusting and the adjoining toilet was repulsive'. Extract of the report on a food and veterinary office mission on Food hygiene in France, 2009

$\mathbf{T}$ he Food Veterinary Office (FVO) assesses conformity to the Food Law in the different member states, on behalf of the European Union. In 2009 its report concluded that France had properly implemented the new approach in slaughterhouses, 
but it was extremely critical of the levels of hygiene in the slaughterhouses visited (FVO 2009a). Similar conclusions were drawn with regard to Italy, (FVO 2008a), Denmark (FVO 2008b) and the UK (FVO 2009b). How can we explain this paradox?

In Europe, the food safety policy combines the regulatory interventions of member states with private standards (Ansell and Vogel 2006; Marsden et al. 2010). The Hygiene Package, which came into force on I January 2006, is characteristic of this model, 'a hybrid of state and non-state actors' (Majone I996; Egan 200I, p. 264). Made up of a series of regulations ${ }^{2}$, its purpose is to ensure food safety at all stages of the production process, from primary production up to and including sale to the final consumer, e.g., from the farm to the fork. It states that food business operators are responsible for the products that they sell and that they must enact safety procedures based on an analysis of the dangers within their premises, in accordance with Hazard Analysis and Critical Control Points (HACCP) $)^{3}$. It thus falls within the movement to extend the good practice guides, quality systems and standards, which regulate farming sectors, agrobusinesses and professional practices (Brunsson and Jacobsson 2000). As these standards are based upon expertise which is perfectly suited to a specific industrial sector (Kerwer 2005; Demortain 2008), they are generally considered to be the most adequate and effective. The Hygiene Package is an example of co-regulation: 'Co-regulation combines binding legislative and regulatory action with actions taken by the actors most concerned, drawing on their practical expertise' (Commission of the European Communities, 200I, p. 2I). Its effectiveness is deemed to be greater for the production of standards, their implementation and their application (Henson and Caswell I999; Eijlander 2005; Garcia Martinez et al. 2007).

We accept that the extension and implementation of private standards vary considerably according to the country and sector (Marsden et al. 2010, p. 267). The aim of our article is to show that whilst we can learn about co-regulation by examining the standards and principles on which it is based, we will gain an even better understanding by examining its actual implementation. With this in mind, we look at how the Hygiene Package was received and implemented in French slaughterhouses. From a sociological standpoint, we describe how government officials are taking these regulations on board and how they are changing the way they work. We then examine how relations between official veterinarians and slaughterhouse workers are evolving on site. In this way we show that whilst a new approach to food safety is certainly being implemented, it is taking distinct forms which are sometimes far removed from the original theoretical intent.

\section{Theoretical framework}

In order to examine the implementation of this new approach to food safety in France, our article offers an analysis of the work carried out by veterinary inspectors in slaughterhouses. Literature on implementation (Bardach I978; Pressman and Wildavsky I984) and on frontline workers (Lipsky 20I0; Maynard-Moody and Musheno 2003; Jeannot 2008) is a reminder that individuals out in the field are major actors of public policies, of their successes and failures. It suggests that the analysis of public action should not be confined to the examination of policymaking, but that it should strive to understand the commitment and practices of 
the actors at both central and local levels. In the case of regulatory policies, sociological analyses are more often than not inspired by Weber's (I922) sociology of law, which sees legal order not as a series of imperatives, but rather as a set of regulatory resources which are mobilised to a greater or lesser extent depending on the situation (Lascoumes I990). Research on the regulators typically looks at the style of regulation that an inspector might personify, from an accommodating approach based on conciliation and co-operation, to a dissuasive or coercive approach which tends more towards repressive measures (Hawkins I984; Reiss I984). This perspective opened the door to numerous studies of greater depth and it is now accepted that regulators successively adopt different approaches, depending on the circumstances, who they are dealing with, the strategies of the monitoring bodies and how they conceive their profession (i.e., Braithwhaite et al. I987; Gormley I997, I998; May and Burby I998; May and Winter 2000; Pautz 2009a). As Harrison et al. (I997) point out, the study of regulatory practices at different levels raises new questions, in particular that of their integration: how can we establish a link between the diversity of the practices observed at local level and a 'single' policy at national or European level?

In this research (with the exception of Pautz 2009b), the regulatory framework in which inspectors operate is stable and unambiguous. In our case, through the Hygiene Package, the new nature of the regulation changes the role and work of the government inspectors responsible for monitoring slaughterhouses. For veterinary inspectors, it is no longer a case of just examining the animals, of carrying out laboratory tests to detect germs and parasites and of verifying food-handling hygiene, but also of ensuring that the HACCP plan defined by the slaughterer is being properly implemented. Studies on the concept of HACCP demonstrate that it is subject to varying interpretations (Untermann I999). For example, Ten Eyck et al. (2006) show that it takes on different significances depending on the actor in the agrobusiness system: Michigan's cider inspectors, food business operators and consumers all understand it in a different way. Furthermore, not only do the tasks change, so does the value that the inspectors give them, along with the hierarchy that they establish between them: whilst meat inspection has been the core activity of inspectors since the nineteenth century, it is now just one task among many. Whilst documentary inspection was part of the red tape - of the 'dirty work' - it is now an obligatory stage of slaughterhouse inspection. With this in mind, our article looks at how the Hygiene Package is changing the inspector's occupations and their relations with slaughterhouses.

\section{Methods}

Our article is based on observations and semi-directive interviews within veterinary services in five French regions, between September 2008 and June 2009. The study took place in slaughterhouses of all sizes, both single and multi-species. Laure Bonnaud spent periods of between three days and several weeks in the inspection services of the slaughterhouses concerned. She met with all inspectors, e.g., official veterinarians and official auxiliaries, taking part in their daily work and then carrying out interviews of varying lengths (one to several hours); finally, she interviewed 
slaughterhouse executives (the directors of the smaller sites and both the directors and the quality managers at the larger sites). The interviews were recorded and then typed out in full in order to allow joint analysis by the authors. Our article is thus based on observations and on the analysis of 83 interviews which took place in 15 different slaughterhouses.

After setting out the structure of slaughterhouses in France and the ways in which veterinary services are organised (I) the article looks at how inspection services have been affected by the introduction of the Hygiene Package, particularly with regard to the changes in relationships within the inspection service, between veterinarians and official auxiliaries, (2) it then examines the evolution in roles and responsibilities between veterinary services and (3) food business operators.

\section{Veterinary inspection in French slaughterhouses}

A longstanding command and control approach. The case of slaughterhouses presents several characteristics which make it particularly heuristic. First and foremost, as elsewhere in Europe, the French government has been intervening to ensure the salubrity of meat since the end of the nineteenth century (Hubscher I999; Koolmees 2000; Enticott et al. 20II). Veterinary inspectors are present both when the animals are delivered and on the slaughter chain, where they examine each carcass and its offal. Their objective is to use their senses and their anatomopathological knowledge to identify lesions and anomalies which show that the animal has a pathology that renders its meat and/or offal unfit for human consumption. Over the course of the twentieth century, the gradual understanding of the connections between animal diseases (trichina, tuberculosis, brucellosis, etc.) and meat which was unfit for consumption led to improved techniques and added to the expertise of veterinarians (Hardy 2003; Stanziani 2005, pp. 223-255). Inspection gradually integrated new knowledge and tools, combining the sensorial approach with laboratory tests (Hardy I999; Stanziani and Atkins 2007) and documentary analysis (Torny I998). These evermore extensive checks nevertheless fell within the traditional 'command and control' approach to food safety regulation, whereby the government enacted rules and ensured their application.

With the Hygiene Package, slaughterhouses remain subject to permanent inspection, e.g., veterinarians continuously check carcasses, just as they used to. But with regard to all other aspects (hygiene, microbiological analyses, etc.) food business operators are fully responsible for the products they sell. They must identify the dangers inherent in the operation of their establishments and come up with a plan setting out the measures they have implemented to prevent or correct said dangers, in accordance with the HACCP method. Veterinary inspectors have a dual role to play: first of all, they authorise establishments to operate by granting a permit, in accordance with the health and hygiene system proposed by the slaughterhouse; secondly, they check that the safety system thus implemented is operational. References for inspection vary, depending on the establishment, its expertise and its manufacturing procedures. In Europe, the Hygiene Package has not changed the systematic inspection of every carcass and HACCP plans coexist with this historical method of monitoring salubrity. The situation is different in the US, where in 1996 the introduction 
of the Pathogen Reduction Act led to the removal of the USDA's federal inspection, whose officials no longer carry out ante- or post-mortem inspections (Juska et al. 2000, p. 262).

Slaughterhouses in France. France is one of the largest agricultural countries in the European Union. It is the leading cattle producer (I,510,000 tons in 2006 and 2I per cent of the production of the member states (Eurostat 2008), the second biggest sheep producer after Spain, and the third largest pig producer after Germany and Spain. The consequence of such a large and diverse production is that France has 262 approved slaughterhouses, 68 per cent of which are multi-species (MAAP 20IO). Slaughter takes place mainly in the west of France: Brittany counts for 39 per cent of slaughter, all species taken together, whilst over half of the slaughter (52 per cent) is carried out in just two regions - Brittany and the Loire region (Figure 1). This geographical concentration goes hand in hand with an industrial concentration, with 4I slaughterhouses in the west (out of 262 , e.g., I5. 6 per cent) carrying out 50 per cent of slaughter in France. This concentration also means that small slaughterhouses, located all over France, coexist with very large abattoirs, essentially in Brittany. In 2007, 204 slaughterhouses were each processing less than I0,000 tons per year, with I29 of them having a capacity below 2,000 tons. The introduction of the Hygiene Package thus took place within a highly heterogeneous landscape.

'Vets'. In an ethnographic work carried out by participant observation, Muller (2008) noted that the slaughterhouse workers called all members of the inspection teams 'vets'. Yet this term covers people with very different levels of experience, qualification and status. The staff in the veterinary services in slaughterhouses include 519 veterinarians, e.g., 26 per cent of the 2010 inspectors working in slaughterhouses (MAAP 20IO). 74 per cent of the inspectors are thus official auxiliaries. Of these II 68 auxiliaries, 78 per cent are civil servants: they passed a competitive examination and received two years of training, both theory and practice, in a vocational school. The remaining members of the inspection teams are contract workers, most of them with fixed-term contracts - they are able to join the teams for a few weeks or months, often without any training. On the other hand, only 49 (9.5 per cent) veterinarians working in slaughterhouses are civil servants: 90.5 per cent are temporary replacements. Some work mainly for the veterinary services and have sometimes been doing so for decades, particularly those in the major abattoirs; others maintain their freelance medical and surgery activities and work from time to time as inspectors, especially when it comes to making decisions on seizure or carrying out ante-mortem inspections. Whatever their status may be, the veterinarians are considered to be in charge of the slaughterhouse inspection service: temporary official veterinarians thus have to manage inspection teams mainly composed of civil servants.

Within the inspection teams, the division of labour has always been very clearly marked. The veterinarians work office hours and never go onto the slaughter chain. The official auxiliaries inspect the meat on the chain and must therefore be present as soon as slaughter begins (between $3 a m$ and $5 \mathrm{am}$ ). Direct observation shows that the two categories of inspector are nevertheless interdependent. Carcass inspection is 


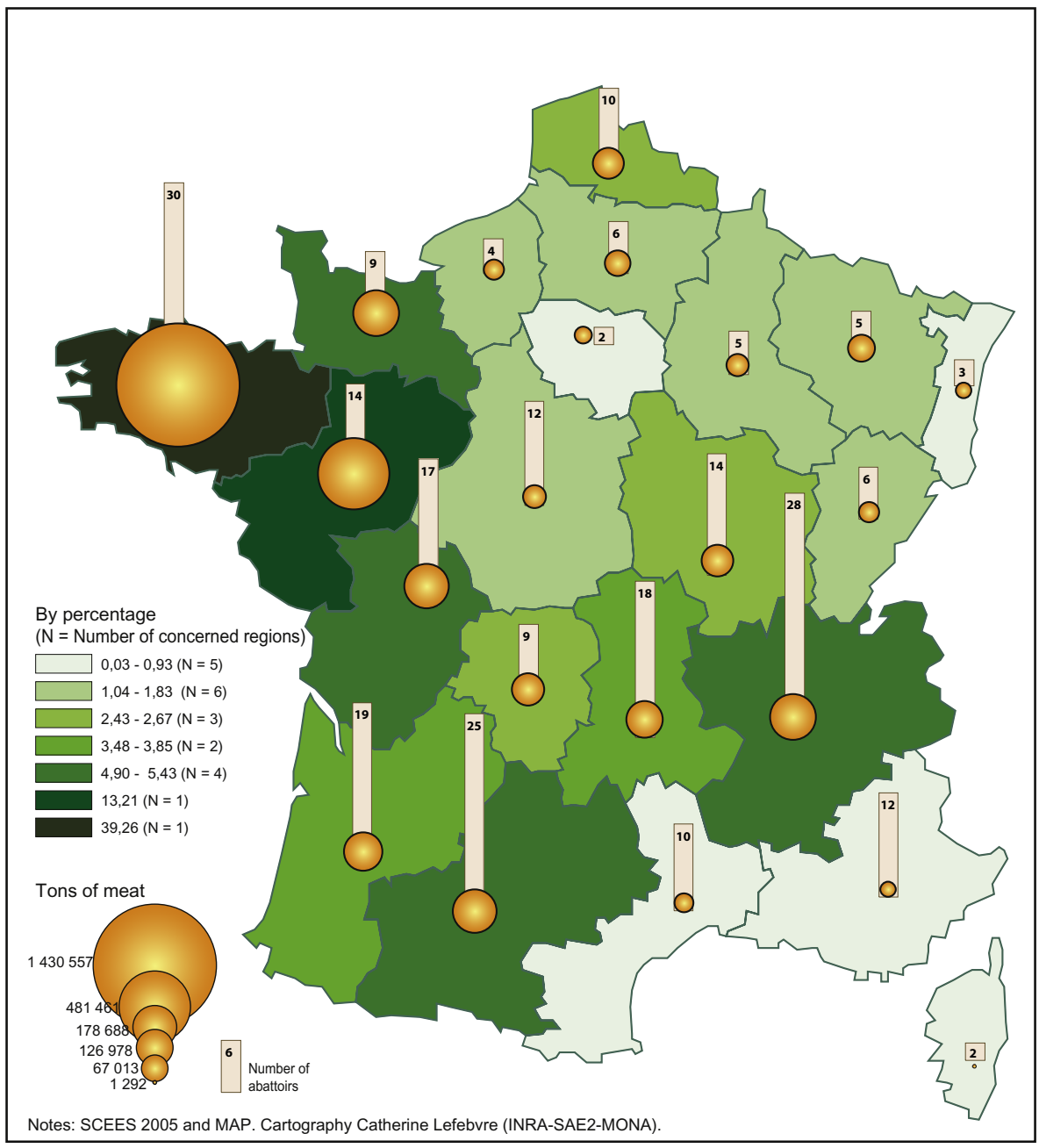

Figure 1: Distribution of slaughter and numbers of abattoirs by French administrative regions

largely a question of experience: the more lesions an inspector has seen, the more easily he can spot them. It is the official auxiliaries who are permanently present on the chain. Yet according to the regulations, seizure decisions must be made by a veterinarian. The latter are often less competent than their team when it comes to detecting anomalies, especially as meat inspection has a poor reputation in veterinary schools. It is therefore very important that veterinarians and official auxiliaries find ways of working together for inspection (Bonnaud and Coppalle 2008). We therefore find several factors of heterogeneousness in the implementation of meat safety policy: 
regulations comprise two types of standard - private and public; French slaughterhouses are very diverse, running from small para-municipal multi-specie slaughterhouses which operate just a few days a week, to those belonging to major industrial groups which work I6-24 hours a day. Finally, the inspectors themselves form a heterogeneous group whose members do not always have the same aspirations. In what ways has the Hygiene Package changed inspections?

The reception and implementation of the Hygiene Package within French veterinary services

In France, the implementation of European food safety regulations led to a reorganisation of veterinary services in slaughterhouses. The Ministry of Food and Agriculture reinforced its tools for monitoring inspections and attempted to more accurately define the role and responsibilities of government officials working in slaughterhouses.

European regulations and inspection reforms. Since the mid-I990s and parallel to the changes in European food safety regulations, French veterinary services have been working on the implementation of quality assurance in inspections, in accordance with the ISO I7020 standard: 'General criteria for the operation of various types of bodies performing inspection'. Those in favour of this decision believe certification by a third party within public administration to be a logical consequence of European directive 93/43 which encourages a quality approach in agrobusinesses (Gerster et al. 2003 , p. 62I). As can be seen from this speech given by the French minister of agriculture on the 27 January 1997, the private sector is seen as a model for the inspection service:

I want you to introduce quality assurance procedures in your service as rapidly as possible. It is vital that we ensure that inspections are perfectly coherent throughout the country, but, more fundamentally, it would be somewhat paradoxical to force upon food business operators obligations that we are not able to meet ourselves.

Concretely procedures and traceability tools have been introduced. Documentary systems are now generalised, with the idea that proper work is work which is done in accordance with an instruction, with its completion being recorded in order to be able to provide any documentary evidence which might be required at a later date by consumers or the courts. At the same time, veterinarians are disputing their administrative attachment to local agriculture development departments. Their representatives are criticising these departments as being linked to the economic interests of breeders and inclined to making deals with farmers' unions. The ISO I7020 approach is thus being brandished as a proof of integrity and impartiality.

As from 2002, veterinarians became independent of agricultural development departments and quality assurance became generalised. The organisation of veterinary inspection is thus moving more towards formalisation, with a view to clarifying who does what and who is responsible for what. What are the consequences for the inspector occupation? 
Formalising practices in a context of permanent inspection. Concretely, the ISO I7020 standard involves formalising inspection methods by introducing written working procedures, acquiring tools for the standardisation of acts (manuals, guidelines, grids) and implementing the traceability of acts. All inspectors have identified this formalisation of practices as representing major change in their occupation, but veterinarians and official auxiliaries do not feel the same way. For the veterinarians in charge of the inspection services, the implementation of quality assurance is seen as a positive sign of the modernisation of administration, which will allow it to achieve greater recognition. The teams, on the other hand, are concerned about how the formalisation of their activity will affect their everyday work. Indeed, official auxiliaries work on a permanent basis with the slaughterhouse workers. They therefore make an effort to maintain good working relations with them, because the latter are in a position to make their job easier (by pointing out suspicious carcasses for example) or, on the contrary, much harder, should they decide to hide problems (Muller 2008). For official auxiliaries, the obligation to spot failings and then put them in writing makes it complicated to maintain relationships with the workers, whose cooperation is needed to carry out the inspection: 'Written reports stigmatise individual responsibilities in relation to incidents and crystallise judgments of individuals' (Reverdy 2000, p. 240). In the following extract, one official veterinarian explains the difference between his own conception and that of his team regarding the recording of inspection activity:

There's this chain foreman, but he doesn't do his job, he asks any old person to remove veal tonsils ${ }^{4}$, someone who knows nothing about it. So the guy told me 'Oh, no-one has ever shown me what to do'. Afterwards I talked to the official auxiliary, who said 'Hang on, I've personally told him four times how to do it'. The problem is that there is no written trace which says 'this operator is incapable of removing Specified Risk Material (SRM), I've told him four times how to do it'. That's something the auxiliary never wrote down. So joint responsibility! For each of the four times we should have been able to find a written trace in the slaughterhouse's internal log, with the auxiliary stating: 'that's four times I've explained to this operator what to do and he still can't do it properly'. But there is no trace. So our responsibility is fully engaged. So there you go! We are jointly responsible and that's something that can lead to a European stamp being withdrawn. (Official veterinarian)

Rather than systematically noting operators' mistakes and sending written reports to their superiors, teams employ various tactics which allow them to note failings whilst at the same time preserving interaction. For example, they might make a joke which shows that they have noticed the operator's mistake and that they are keeping an eye on him or her, and they always prefer to explain, to demonstrate the correct way of doing things or to 'make do' with the people they are inspecting, in an approach that they describe as 'pedagogical'. In theory, such behaviour is not compatible with the introduction of quality assurance for inspections, which involves a written report for each action of inspection. A barrier is thus being built between official auxiliaries, who work alongside operators, and the veterinarians who manage the service. Here we encounter the results highlighted in the field of social politics (Standfort 2000): regulations of formalisation create a rift between managers and the personnel out in the field. 
Authority and power in the inspection process. Because it strengthens recognition of professional expertise, the Hygiene Package is also contributing towards veterinarians and official auxiliaries developing different conceptions of their occupation.

As they permanently share the life of workers in the slaughterhouse hall, the primary concern of official auxiliaries is to make their position as enforcers clear, as a condition for being able to exercise their functions:

In the same way, a rule enforcer is likely to believe that it is necessary for the people he deals with to respect him. If they do not, it will be very difficult to do his job; his feeling of security in his work will be lost. Therefore, a good deal of enforcement activity is devoted not to the actual enforcement of rules, but to coercing respect from the people the enforcer deals with. (Becker 1997, p. 158)

They thus prefer to inspect from a position of authority, which takes concrete form in the immediacy of the observation and sanction, thus strengthening their position as enforcers. For example: an auxiliary notices a dirty or incorrectly labelled tub; he/she immediately asks an operator to clean it or change it. This type of action is only possible if the inspector and the person being inspected share the same reference point for the situation in question, such as a rule. With the Hygiene Package, it is the standards introduced by the slaughterhouse, brought together within the HACCP plan, which constitute the reference point for assessing situations and the slaughterhouse must correct the mistakes which are discovered in the implementation of its own procedures. According to the French ministry's directives, inspectors must 'ensure that the company has taken steps to properly verify the implementation of the HACCP plan. They must under no circumstances verify the plan itself in the company's place'. This new directive marginalises the capacity of inspectors to sanction errors in hygiene and changes the nature of their interventions. It makes it much harder to apply an immediate sanction.

The following extract illustrates the helplessness of an auxiliary who is confronted with a clearly irregular situation but who cannot see how to ensure that it is recognised as such. In accordance with practices prior to the Hygiene Package, he would like his word and his senses (sight, smell, touch) to be sufficient proof. But facts must now be proven in an entirely different manner, based on risk analysis:

The other day, with the pigs ... they'd made a chain which was much too fast. When the pig arrived for singeing, the flame worked for two seconds, and then, in fact, it became a continuous chain. The flame remained a flame, so the safety system went off and there was "glycolene" all over the pigs! The slaughterer finally said that we had to seize 22 of them. So I asked the veterinary surgeon: 'Why 22? Why not 25 or 28?' 'The slaughterhouse said so!'... They must have done some calculations I suppose ... but still! I said: we are the veterinary service and yet we're unable to say 'No, this one smells bad too! We'll take this one as well! ... That's why ... when it happens again and again ... We get discouraged. (Official auxiliary)

In this example, the auxiliary would like his authority to suffice for taking decisive and immediate action: you stop the chain, you withdraw the affected pig carcasses from consumption. As for veterinarians, they fall within the framework of the new Hygiene package and monitor the operator's risk analysis and procedures, which leads them to defer judgement and then to accept the conclusions of the slaughterhouse's assessment. In so doing, they come into conflict with their teams, who felt that an 
unacceptable incident had taken place without any reaction from the inspection service.

With the changes that have been made to the inspection process, teams are finding this type of misunderstanding to be increasingly frequent. Veterinarians share their teams' opinions on irregular situations, but they often disagree about the type of solution that is required. They favour inspections which take place in a situation of power, e.g., where their actions cannot be challenged at a regulatory or technical level. Official auxiliaries feel that they have lost all power, the latter having shifted over to the veterinarians, who decide whether or not to confirm their decisions.

We thus find a new hierarchy in inspection tasks: the professional pride of official auxiliaries had for a long time been defined by the fact that they were guardians of meat quality on behalf of consumers - they were the ones who removed carcasses unfit for the food chain and who, through their inspections, ensured that there was a satisfactory level of hygiene in the various establishments. This activity has now become marginalised, partly due to overall improvements in animal health and partly due to changes in regulations, which are now based on the procedures used by the slaughterhouses themselves. Because veterinarians are responsible for the implementation of this new approach, they tend to work less closely with their teams. Paradoxically, within this evolution, official auxiliaries have greater specific knowledge and veterinary expertise (in relation to lesions and animals) than their heads of department. The latter tend to focus on risk analysis, procedures and the engineering in agrofood establishments, skills relating to production systems and modes of organisation which are normally associated with quality control managers. In this way the Hygiene Package helps to redefine veterinary expertise, as Enticott et al. (2OII) have shown in other fields.

The Hygiene Package thus very significantly modifies relations within the inspection service, as well as the role and status of veterinary expertise. What is the situation regarding relations with the slaughterhouses?

Relationships between inspectors and inspecteed since the implementation of the Hygiene Package

Co-regulation supposes that each party, both State and slaughterhouses, plays a role in the new regulatory framework and fully accepts the responsibilities it entails. Given that France is characterised by the considerable heterogeneousness of its slaughterhouses, how do inspectors and meat business operators approach these new roles?

When the heterogeneous nature of slaughterhouses leads to diversity within the inspector occupation. The Hygiene Package allows food business operators greater latitude to analyse risks and develop their own procedures. However, this opportunity that the Food Law provides is not always taken up. In certain smaller establishments, there are limited resources with which to analyse risks and develop an HACCP plan, especially at the human level: trainees, quality managers with fixed-term contracts or working at multiple sites, etc. (Worosz et al. 2008):

Although we have had a quality department for the last four years, now this suddenly arrives! We get the Hygiene Package, we get authorisations, so my staff and me, we are 
always playing catch-up, we aren't a driving force at all! (Site Director, multi-species slaughterhouse)

Faced with this situation, certain officials from the veterinary service help with the development of the HACCP plans in order to ensure a minimum level of food safety and regulatory conformity: they suggest stages for completing the work, advise on recruitment, on critical issues, document models, etc. (Bonnaud and Coppalle 2008). Reasoning in a similar manner to certain researchers (DeLind and Howard 2008), inspectors feel that the risks are not the same for all establishments and that smaller structures must be preserved because they deal with specific production types (quality labels and short circuits). In so doing, they see themselves more as educators than as enforcers (May and Wood 2003).

On the other hand, meat business operators who have taken the new regulations fully on board want the administration to withdraw its approval of establishments, which are unable to apply the Hygiene Package in its totality. At the same time, they lament that the responsibilisation of producers by the Food Law does not mean the end of permanent inspection. When it comes to adopting the HACCP method, we can therefore see important differences between slaughterhouses (Henson and Hooker 200I). The development of an HACCP plan is a good example of this confusion: in all of the establishments studied, the description of the veterinary service's activities was a real headache for the drafters. How to describe the inspection activity, which involves withdrawing carcasses unfit for consumption from the chain? Certain slaughterhouses considered that this made their industrial process safer, whereas others described this stage as a 'critical point' in as much as it could be performed in error. No general rule has been found to resolve this issue, which is now decided on a case-by-case basis.

More generally, the day-to-day operation of these establishments makes any strict task or responsibility sharing between inspectors and slaughterhouses impossible. To illustrate this point, let us take the case of one of the slaughterhouses in the study, which defined a CCP for the processing of soiled carcasses: they must be marked with an ' $\mathrm{S}$ ' and withdrawn from the slaughter chain. But because it is too restrictive, this procedure is never applied, which leads to the veterinary team intervening:

In the cutting room, they have problems with salmonella and coliforms. There's too much faecal matter, too much negligence. I'm on the chain and for me it's obvious. They wanted to set up a system for faecal matter. The quality manager came: we had to remove them and no longer touch them. He finally gave up, because there were so many pigs being diverted off the chain that there was a rebellion by the workers: 'we've been working this way for I5 years, why change?' He gave in. So we went back to our own way of doing things: faecal matter removed to a greater or lesser extent, depending on the veterinary service. Faecal matter is the only critical issue in the HACCP. It's not normally up to us to deal with the problem, we're supposed to check that it's been properly dealt with. But the problem hasn't been dealt with. We're the ones dealing with the problem, more or less, through debridement. (Official auxiliary)

This example highlights the confusion between the acts performed by slaughterhouse workers and those carried out by the veterinary service: the latter cannot envisage limiting themselves to making observations without intervening when faced with 
clear cases of insalubrity. They therefore act as a substitute for the ineffective procedure and debride the carcasses where they are visibly soiled. In this way the carcasses are undoubtedly cleaner, but as slaughterers, inspectors are far from the roles and responsibilities defined for them by the ISO I7020 standard and the Hygiene Package.

The ecology of monitoring professions. In this new context, many veterinary inspectors feel that their occupation is being called into question. Indeed, the introduction of the HACCP logically supposes a food safety system which is constantly being improved, which is based on self-monitoring and which is validated from time to time by outside audits. This new factor is causing them to reconsider the need for permanent inspection, along with the types of skill and person required for the audits. Some of them believe that the certifying organisations might, or even should, replace them.

People expect us to carry out an inspection, based on comparison with a standard. Quality assurance tells us: 'You have a standard and you do your inspections in accordance with a standard, you do an audit and you say what is wrong compared to the standard. Then you add it all up and you make your conclusions'. Quite often on a certain number of points, things just aren't right! And you think, great! What's the point? WHAT'S THE POINT? Of saying: there's this point, that point and another point which don't conform. If that's all we do! What's the point? If it's an inventory so that the people know where they stand on their health barometer, what the hell is a PUBLIC inspector doing there? You privatise, end of story! (Official veterinarian)

There has been a significant increase in the number of slaughterhouse audits (with one every two weeks during the period of the study) be they appointed by the customers or auditors who come to grant or confirm a quality label (on the increasing number of audits, see Power I999). During the interviews, site directors all compared the different checks that are made, which lends weight to the notion of competition between inspectors from the veterinary service and outside auditors. One might therefore make the hypothesis of a jurisdictional conflict between the State inspectorate and audit organisations, e.g., between two professional groups who carry out the same tasks and whose aim is to maintain a settlement as food safety enforcers by the division of labour (Abbott I988). To which aspects does this competition relate?

From the point of view of the slaughterhouses, we observed that the forms taken by the inspection were only rarely mentioned. The written exchanges are of course deemed to be clearer, but at the same time many of the interviews stressed the secondary nature of this evolution: 'It's intellectualism!' The comparison between different inspectors related more to the checklist and caused the slaughterers to judge the auditors as being more demanding than the veterinary inspectors.

Our main audits are for catering companies: Sodexo, Compass, Elior and Avenance if you prefer, along with Eurest. Second type of auditor, distributor's brands and slaughterhouses! And slaughterhouses! Because I5 per cent of our turnover comes from intermediate food products ... So that's a lot of people, and the biggest pains in the neck are the slaughterhouses. People like us in fact! Next to them, the veterinary service is peanuts! (Quality Manager, pig slaughterhouse) 
We might nevertheless ask ourselves if this quality is proper to outside auditors or if it reflects the greater importance that slaughterhouses attach to the auditors appointed by their customers. The slaughterhouses highlight the firmer requirements for repairs to premises, revised circulation or more restrictive microbiological criteria. Veterinary inspectors recognise how these customer audits act as a spur to back costly investment decisions or to improve operating hygiene. Yet in his work on operators' attitudes during inspections, Muller (2002) demonstrated that workers adapted to visitors in accordance with what they thought the latter's expectations to be: as far as they are concerned, it is not a case of the extent to which they must conform with regulations or specifications or with a checklist, but the extent to which they must adapt to the inspectors. When listening to what slaughterers say, one first and foremost remarks the priority that they set themselves: to adapt to the point of reference that they deem to be the most important - that of their customers.

Comparison between the different types of inspectors also depends on the quality of their specialist knowledge. All of the slaughterhouses visited stressed that they needed to see that the veterinarians possessed technical expertise, in order to monitor regulatory changes in small slaughterhouses or, for the highly industrialised abattoirs, to fall in line with a perspective of export and certification in relation to other countries (US, Japan, Korea, etc.).

I'm in no way trying to say that the veterinary service in charge of the inspection and the slaughterhouses should be in connivance. That's not what I mean at all! They both have to play their role and take their responsibilities, and the veterinary service's power to inspect and then to punish if there are breaches, there's no question, we must have that and we must continue, because we can see that we don't do too badly when there are health crises. On the other hand, I don't think that should prevent us from having a closer relationship within the overall scheme of things. A stronger partnership and greater proximity would be good for economic development (we need to use the word without worrying about shocking people) and would therefore better valorise the French export. I think such proximity is really lacking. (Site Director, pig slaughterhouse)

Finally, for the meat business operator, the point of comparing inspectors and auditors is not to determine who works the most efficiently, but to demand that the veterinary service do more than just inspect. Contrary to recent changes in the regulation and to what veterinary inspectors demand, they ask for a more comprehensive practice, more in line with the partnership between slaughterhouses and States described in certain developing countries (Ponte 2007).

\section{Conclusion}

Our study offers possible explanations for this apparent paradox: that of proper application of the regulations but very poor results regarding operation and hygiene. Implementation of the Hygiene Package is not just a question of applying regulations and standards. It involves social relations in a world where inspectors and inspectees rub shoulders on a daily basis. But within the new regulatory framework, the definition of the roles of government officials and slaughterhouse operators is far from unambiguous. First of all, the inspectors continue to inspect every carcass in the chain, a domain where they have retained all of their prerogatives. For all other 
aspects, it is the slaughterhouse's HACCP plan which applies, a plan over which the veterinary inspectors hold little sway. Secondly, implementation of the Hygiene Package has changed the ways in which the veterinary service and slaughterhouses are organised and has led to a global movement which aims to clarify each party's responsibilities through formalisation. But on a day-to-day basis it is extremely difficult to always report on what everybody is doing and everyone thinks that it is illusory or even somewhat artificial to focus on recording systems. So, aware that such a strict and formal separation is futile, everyone is asking for better communication, contrary to the principles which drove the development of the food safety system. Finally, co-regulation describes the management of food safety by organising public and private actors around technical standards, which supposes the gradual removal of the sovereign figurehead of the State. On-site observation shows that recourse to the State occurs on a daily basis: in well-run abattoirs it remains the last resort in cases of clear danger; its presence prevents small slaughterhouses from being excluded, the latter providing a vital service to local farmers (organic farming, mountain breeders). We therefore find differentiated governance, which maintains the common objective of food safety for meat placed on the market, but which takes different forms.

The actors involved in the co-regulation are aware of this heterogeneousness, even if they do not necessarily appreciate its scope or modalities. Whilst everyone agrees that it needs to be reduced, they all have different solutions: as representatives of public authorities, veterinarians believe that it is through formalised legal instruments, of a similar nature throughout the country, that the harmonious application of regulations will be improved. Official auxiliaries believe their professional know-how when it comes to recognising wholesome meat and their professional conscience in promoting hygiene to be cornerstones for any homogeneous implementation of regulations. The largest slaughterhouses consider that health regulations should be based more on standards and that permanent slaughterhouse inspections are a source of distortion and should be gradually phased out. In this way, fair competition rules can be enforced throughout Europe, thus weeding out incompetent professionals whilst at the same time allowing the most competent to expand. Finally, the smaller slaughterhouses find it hard to see health regulations as anything other than a constraint on profitability.

This conclusion is in turn an argument in favour of sociological work being carried out on these subjects in the different member states.

\section{Notes}

* Corresponding author.

I La Parmentière is a manufacturer of equipment for slaughterhouses. In this sentence, 'la Parmentière' refers to a paunch cleaning machine

2 The founding text is Regulation I78/2002, or the 'Food Law', amended in 2004 by regulation $852 / 2004$ on the general rules of hygiene for foodstuffs of animal origin; Regulation 853/ 2004 on the specific rules of hygiene for foodstuffs of animal origin; Regulation 854/2004 setting out the specific rules for the organisation of official inspections; Regulation 882/2004 on official inspections.

3 The HACCP is a method based on seven principles: (I) Identify potential consumer health hazards, (2) Identify the control points where the identified hazards may occur, (3) Establish 
critical limits for the potential hazards and safety measures, (4) Establish monitoring routines to ensure safety measures are working, (5) Establish appropriate responses if monitoring indicates a problem, (6) Establish accurate and detailed record-keeping system that documents problems and the remedial steps to be taken and (7) Establish a verification system that ensures the above steps are being followed.

4 As part of the prevention of BSE, tonsils have been removed from the food chain in Europe.

\section{References}

Abbott, A. (I988) The system of professions: an essay on the division of expert labor (Chicago, IL: The University of Chicago Press)

Ansell, C.K. and D. Vogel (2006) What's the beef? The contested governance of European food safety (Cambridge, MA: MIT Press)

Bardach, E. (I978) The implementation game: what happens after a bill becomes a law (Cambridge, MA: The MIT)

Becker, H.S. (I997) Outsiders: studies in the sociology of deviance (New York: Simon \& Schuster Ltd)

Bonnaud, L. and J. Coppalle (2008) La production de la sécurité sanitaire au quotidien: l'inspection des services vétérinaires en abattoir. Sociologie Du Travail 50 (I) pp. I5-30

Braithwhaite, J., J. Walker and P. Grabosky (I987) An enforcement taxonomy of regulatory agencies. Law and Policy 9 (3) pp. 323-35I

Brunsson, N. and B. Jacobsson eds (2000) A world of standards (Oxford: Oxford University Press)

Commission of the European Communities (200I) European governance. A white paper, COM(200I) 428 - Available online at http://eur-lex.europa.eu/LexUriServ/site/en/com/ 200I/com200I_0428enoi.pdf Accessed i3 Aug 20I3

DeLind, L. and P.H. Howard (2008) Safe at any scale? Food scares, food regulation, and scaled alternatives. Agriculture and Human Values 25 (3) pp. 30I-3I7

Demortain, D. (2008) Standardising through concepts. The power of scientific experts in international standard-setting. Science and Public Policy 35 (6) pp. 391-402

Egan, M. (200I) Constructing a European market (Oxford: Oxford University Press)

Eijlander, P. (2005) Possibilities and constraints in the use of self-regulation and co-regulation in legislative policy. Experiences in the Netherlands-Lessons to be learned for the EU? Electronic Journal of Comparative Law 9 (I) pp. I-8

Enticott, G., A. Donaldson, P. Lowe et al. (2OII) The changing role of veterinary expertise in the food chain. Philosophical Transactions of the Royal Society B 336 (1573) pp. I955-1965

Eurostat (2008) Food: from farm to food statistics (Luxembourg: Office for Official Publications of the European Communities)

FVO (2008a) Final report of a mission carried out in Italy from May to 23 May 2008 in order to evaluate the follow-up action taken by the competent authorities with regard to official controls related to the safety of food of animal origin, in particular meat and milk (Brussels: European Commission, DG (SANCO)/2008-7930 - MR - FINAL)

FVO (2008b) Final report of a mission carried out in Denmark from 2I October to 3I October 2008 in order to evaluate the follow-up action taken by the competent authorities with regard to official controls related to the safety of food of animal origin, in particular meat and milk (Brussels: European Commission, DG (SANCO)/2008-7942 - MR - FINAL)

FVO (2009a) Report on a Food and Veterinary Office Mission to France from I5 to 26 June 2009 in order to evaluate official controls related to the safety of food of animal origin, in particular meat, meat and their products (Brussels: European Commission, DG (SANCO)/2009-823I)

FVO (2009b) Final report of a specific audit carried out in the United Kingdom from 05 May to I5 May 2009 in order to evaluate the follow-up action taken by the competent authorities with regard to official controls related to the safety of food of animal origin, in particular meat, milk and their products in the context of a general audit (Brussels: European Commission, DG (SANCO)/ 2009-8225 - MR - FINAL) 
Garcia Martinez, M., A. Fearne, J. Caswell et al. (2007) Co-regulation as a possible model for food safety governance: opportunities for public-private partnerships. Food Policy 32 (3) pp. 299-3I4

Gerster, F., N. Guerson, V. Moreau et al. (2003) La mise en place d'une démarche d'assurance qualité: exemple des Services vétérinaires français. Revue Scientifique Et Technique De l'Office International Des Epizooties 22 (2) pp. 597-628

Gormley, W.T. (I997) Regulatory enforcement: accommodation and conflict in four state. Public Administration Review 57 (4) pp. 285-293

Gormley, W.T. (I998) Regulatory enforcement styles. Political Research Quaterly5I (2) pp. 363-383

Hardy, A. (I999) Food, hygiene and the laboratory: a brief history of food poisoning, circa I850-I950. Social History of Medicine I2 (2) pp. 293-3II

Hardy, A. (2003) Animals, disease and man. Making connections. Perspectives in Biology and Medicine 46 (2) pp. 200-215

Harrison, M., A. Flynn and A. Marsden (I997) Contested regulatory practice and the implementation of food policy: exploring the local and national interface. Transactions of the Institute of British Geographers 22 (4) pp. 473-487

Hawkins, K. (I984) Environment and enforcement: regulation and the social definition of pollution (Oxford: Clarendon Press)

Henson, S. and J. Caswell (I999) Food safety regulation: an overview of contemporary issues. Food Policy 24 (6) pp. 589-603

Henson, S. and N.H. Hooker (200I) Private sector management of food safety: public regulation and the role of private controls. International Food and Agribusiness Management Review 4 pp. 7-I7

Hubscher, R. (I999) Les maîtres des bêtes. Les vétérinaires dans la société française (xviiie-xxe siècle) (Paris: O. Jacob)

Jeannot, G. (2008) Les fonctionnaires travaillent-ils de plus en plus? Un double inventaire des recherches sur l'activité des agents publics. Revue Française De Science Politique 58 (I) pp. I23-I4O

Juska, A., L. Gouveia, J. Gabriel et al. (2000) Negotiating bacteriological meat contamination standards in the US: the case of E. coli Or57:H7. Sociologia Ruralis 40 (2) pp. 249-27I

Kerwer, D. (2005) Rules that many use: standards and global regulation. Governance: An International Journal of Policy, Administration and Institutions I8 (4) pp. 6II-632

Koolmees, P.A. (2000) Veterinary inspection and food hygiene in the twentieth century. Pp. 55-68 in D.F. Smith and J. Phillips eds, Food, science policy and regulation in the twentieth century (London and New York: Routledge)

Lascoumes, P. (I990) Normes juridiques et mise en œuvre des politiques publiques. L'Année Sociologique 40 pp. 43-7I

Lipsky, M. (20I0) Street-level bureaucracy: dilemmas of the individual in public services (New York: Russell Sage Foundation)

MAAP (20IO) Extrait du logiciel Sigal pour le bureau des abattoirs (Paris: Ministère de l'Alimentation, de l'Agriculture et de la Pêche)

Majone, G. (1996) Regulating Europe (London: Routledge)

Marsden, T., R. Lee, A. Flynn et al. (20I0) The new regulation and governance of food. Beyond the food crisis? (New York and London: Routledge)

May, P.J. and R.J. Burby (I998) Making sense out of regulatory enforcement. Law and Policy 20 (2) pp. I57-I82

May, P.J. and S. Winter (2000) Reconsidering styles of regulatory enforcement: patterns in Danish Agro-Environmental Inspection. Law Q Policy 22 (2) pp. I43-I73

May, P.J. and R.S. Wood (2003) At the regulatory front lines: inspectors' enforcement styles and regulatory compliance. Journal of Public Administration Research and Theory (2) pp. II7-9

Maynard-Moody, S. and M. Musheno (2003) Cops, teachers, counsellors: stories from the frontlines of public services (Ann Arbor, MI: University of Michigan Press) 
Muller, S. (2002) Visites à l'abattoir: la mise en scène du travail. Genèses. Sciences Sociales et Histoire 49 (4) pp. 89-Io9

Muller, S. (2008) A l'abattoir (Paris: Quae)

Pautz, M. (2009a) Trust between regulators and the regulated: a case study of environmental inspectors and facility personnel in Virginia. Politics a Policy 37 (5) pp. I047-IO72

Pautz, M. (2009b) Next generation policy and the implication for environmental inspectors: are fears of regulatory capture warranted? Presentation at the 2009 Midwest Political Science Association Annual Conference. 2-5 April 2009. Chicago, Illinois

Ponte, S. (2007) Bans, tests, and alchemy: food safety regulation and the Uganda fish export industry. Agriculture and Human Values 24 (2) pp. I79-I93

Power, M. (1999) The audit society: rituals of verification (Oxford: Oxford University Press)

Pressman, J.L. and A. Wildavsky (I984) Implementation: how great expectations in Washington are dashed in Oakland 3rd edn (Los Angeles, CA: University of California Press)

Reiss, A. (I984) Selecting strategies of social control over organizational life. Pp. 23-35 in K. Hawkins and J. Thomas eds, Enforcing regulation (Boston, MA: Kluwer-Nijhoff Publishing)

Reverdy, T. (2000) Les formats de la gestion des rejets industriels: instrumentation de la coordination et enrôlement dans une gestion transversale. Sociologie Du Travail 42 (2) pp. $225-243$

Standfort, J.R. (2000) Moving beyond discretion and outcomes: examining public management from the front lines of the welfare system. Journal of Public Administration Research and Theory io (4) pp. 729-756

Stanziani, A. (2005) Histoire de la qualité alimentaire (Paris: Seuil)

Stanziani, A. and P. Atkins (2007) From laboratory expertise to litigation: the municipal laboratory of Paris and the London inland revenue laboratory, I870-I9I4. A comparative analysis. Pp. 317-339 in C. Rabier ed., Fields of expertise: a comparative history of expert procedures in Paris and London, I600 to present (Newcastle: Cambridge Scholars Publishing)

Ten Eyck, T.A., D. Thede, G. Bode et al. (2006) Is HACCP nothing? A disjoint constitution between inspectors, processors and consumers and the cider industry in Michigan. Agriculture and Human Values 23 (2) pp. 205-2I4

Torny, D. (I998) La traçabilité comme mode de gouvernement des hommes et des choses. Politix 44 (4) pp. 5I-75

Untermann, F. (I999) Food safety management and misinterpretation of HACCP. Food Control Iо (3) pp. I6I-IG7

Weber, M. (I922) Wirtschaft und Gesellschaft I980 Edition (Tubingen: Möhr)

Worosz, M.R., A.J. Knight and C.K. Harris (2008) Resilience in the US red meat industry: the roles of food. Agriculture and Human Values 25 (2) pp. I87-I9I

Laure Bonnaud*:

INRA - RiTME

UR 1323

65, boulevard de Brandebourg

94205 Ivry-sur-Seine Cedex

France

e-mail: laure.bonnaud@ivry.inra.fr

Jérôme Coppalle

Ecole Nationale des Services Vétérinaires

1 , avenue Bourgelat

69280 Marcy l'étoile

France

e-mail: jerome.coppalle@agriculture.gouv.fr 